\title{
Morphological skin evaluation in the patients with systemic scleroderma before and after hematopoietic stem cell trans- plantation
}

\author{
Galina V. Fedotovskikh, Galija M. Shaymardanova, Manarbek B. Askarov, Ainash A. Zhusupova, Natalya A. Krivoruchko, \\ Tatyana G. Ezhelenko, Sapargul Marat
}

National Scientific Medical Center, Nur-Sultan (Astana), Kazakhstan

Prof. Galina V. Fedotovskikh, MD, National Scientific

Medical Center, Abylaikhan Avenue 42, 010000, Nur-Sultan

(Astana), Kazakhstan
Phone: +7 (707) 2223256

E-mail: gvf_fedotovskikh@mail.ru

Citation: Fedotovskikh GV, Shaymardanova GM, Askarov MB et al. Morphological skin evaluation in the patients with systemic scleroderma before and after hematopoietic stem cell transplantation. Cell Ther Transplant 2020; 9(2): 60-66.

\section{Summary}

Some promising clinical results of hematopoietic stem cell transplantation (HSCT) are reported in severe autoimmune diseases. When treating the patients with systemic scleroderma (SSD), histological evaluation of skin fibrosis includes scoring of myofibroblasts that are associated with excessive deposition of extracellular matrix components. The aim of our study was to evaluate morphological condition of skin in SSD patients before and after transplantation of autologous hematopoietic bone marrow stem cells.

\section{Patients and methods}

Twenty-eight patients were observed at the National Research Medical Center (Nur-Sultan), at the age of $45+11$ years old ( 2 males, 26 females) with verified diagnosis of SSD according to ACR/EULAR (2013). Duration of the disease was $12+5.4$ years old. Control group ( 12 persons) received conventional basic therapy Treatment protocol for the main group included autologous HSCT. Resistance to immunosuppressive therapy was a pre-requisite for HSCT.

Bone marrow aspiration was performed from the iliac crest, the autologous mononuclear cells were isolated in Percoll density gradient and incubated for 72 hours at $37^{\circ} \mathrm{C}$. Autologous HSCT was performed at a mean dose of $88 \times 10^{6}$ cells in $200 \mathrm{~mL}$ of physiological saline $\mathrm{i} / \mathrm{v}$ over 3 hours. Clinical effect was evaluated by the recognized criteria (European Scleroderma Trials and Research Group, skin score by Rodnan). For morphologi- cal studies, the punch biopsies of tibial skin were taken in 15 patients before therapy, and in 9 three months after the treatment. The cellular therapy was accompanied by improved skin condition. The paraffin sections were stained with hematoxilin and eosin, as well as by Masson-trichrome technique. For electron microscopy, the skin biopsies were processed by conventional method, then being Epon-embedded. Semi-thin slices were stained with Methylene Blue, Azur II and basic fuchsine. For EM, the ultrathin sections were contrasted with uranyl acetate and lead citrate.

\section{Results}

Skin of SSD patients before treatment was characterized by induration and dystrophy and epithelial destruction, sclerosis and hyalinosis of dermal connective tissue, pathology of microcirculatory vessels. Ultrastructure of myofibroblasts in the sclerotized derma was characterized by functional overload. The active participants of fibrillogenesis were located in perivascular area, being represented by lymphocytes and fibroblasts of a specific SSD-specific population producing higher amounts of collagen and interstitial matrix. However, three months after HSCT, the main group of the patients exhibited a pronounced clinical effect with sufficient decrease of skin induration, reduced dysphagia, mitigation of muscle contractures, couping vasospasm attacks (Raynaud syndrome). Skin density was significantly decreased, with Rodnan scores changed from 12.9 to 8.7 (only 1-point decrease in the controls). HSCT promoted biodegradation of skin fibrotic tissue in SSD patients. The myofibroblasts were subjected to destruction, multiple 
and prolonged capillaries were observed, the cell composition of perivascular infiltrate shifted to normal state. Numerous phagocytic and secretory macrophages appeared, thus suggesting angiogenesis induction, tissue remodeling, regulation of fibroclast population, suppression of T- and B-lymphocytes playing an important role on SSD pathogenesis. Extensive telocyte connections presumed their participation in neoangiogenesis and transmission of regeneration signaling.

\section{Conclusion}

Transplantation of cultured autologous hematopoietic marrow stem cells in SSD patients promoted biodegradation of sclerotized dermal layer, as well as angiogen- esis stimulation, restoration of epithelium and skin appendages 3 months after HSCT, thus corresponding to improvement of clinical symptoms.

\section{Keywords}

Systemic scleroderma, hematopoietic stem cell transplantation, bone marrow, skin morphology.

\section{Introduction}

Studies in molecular pathogenesis of autoimmune activation, vascular pathology and excessive fibrosis in systemic scleroderma (SSD) have provided basis for effective target therapy aimed for immune modulation, antiproliferative and antifibrotic treatment of this disorder [1]. Over last decades, an important role in successful treatment of autoimmune diseases, e.g., SSD, is given to a complex multifaceted effects of hematopoietic stem cell transplantation (HSCT) which sufficiently increases efficiency of preceding high-dose immunosuppressive therapy [2]. Recent clinical reports evaluating HSCT for treatment of severe autoimmune diseases show quite promising results [3]. As a rule, histological control of skin fibrosis changes in the course of treatment includes enumeration of myofibroblasts that are associated with excessive deposition of extracellular matrix components [4]. In cases of positive clinical changes in the SSD patients after HSCT, we were focused on the light microscopy, histochemical, and ultrastructural changes of skin which may be connected with therapeutic effects of the cellular therapy.

The aim of our study was to evaluate morphological and functional state of skin from the SSD patients before and after autologous transplantation of pre-cultured hematopoietic stem cells from bone marrow.

\section{Patients and methods}

We have observed twenty-eight patients at the National Scientific Medical Center (Nur-Sultan), aged 26 to 60 years (2 males and 26 females) with identified diagnosis of SSD, according to ACR/EULAR criteria [5]. The duration of the disease was more than 3 years. In the frame of clinical examination, we performed general laboratory assessment, immunological tests, CT of thoracic area, echo-CG with measuring blood pressure in A. pulmonalis. All the patients exhibited skin thickening on both hands, ulceration (3\%), digital ischemia (43\%). Rainaud syndrome was expressed in $98 \%$ of the patients, teleangiectasias in $84 \%$, esophagopathy, in $51 \%$. CT of thoracic area showed interstitial lung affection in $35 \%$ cases, pulmonary hypertension in $15 \%$ of cases. Rodnan skin scores were determined before and after therapy. The patients were divided into 2 groups without any significant differences for age, duration of disease, and skin scores.
The patients received the following basic therapy: plaquenil (hydroxychloroquine) at $200 \mathrm{mg} /$ day, prednisolone (a mean of $6.9+2.1 \mathrm{mg} /$ day $)$, methotrexate $(10-15 \mathrm{mg} /$ week $)$, azathioprine (50-100 mg/day). The control group consisted of 12 patients. The main group (16 persons) was additionally treated with hematopoietic stem cell (HSC) transfusion. Resistance to immunosuppressive therapy was a reason for HSAC transplantation.

After clinical and laboratory examination of the SSD patients, 200 to $300 \mathrm{~mL}$ of bone marrow was aspirated via tibial crest with local or peridural anaesthesia under sterile conditions in the surgical block. Isolation of autologous mononuclear bone marrow cells was performed by centrifugation in Percoll density gradient (Sigma Aldrich, P1644). The isolated cell were cultivation in DMEM medium (Dulbecco Modified Eagles Medium, Sigma Aldrich, D1145) with 10\% FBS at $37^{\circ} \mathrm{C}$ for 72 hours. Cell viability was determined by trypan blue staining. Quantification of dual-positive CD45+/ CD34+mononuclear cells ' count was done on the BD FACSCalibur flow cytometer (Becton, Dickinson and Company, BD Biosciences, San Jose, CA, USA).

Transfusion of autologous cultured HSCs was carried out in physiological saline (a mean of $140 \times 10^{6}$ cells per $200 \mathrm{~mL}$ ) intravenously dropwise, at a rate of $50 \mathrm{~mL} / \mathrm{h}$. Clinical efficiency (Rodnan skin scores) was evaluated by the criteria of European Scleroderma Trials and Research Group [6].

Tibial skin bioptates were taken using punch biopsy in 15 patients before cellular therapy and in 9 cases at 3 months after auto-HSCT, upon clinical improvement of skin condition. The paraffin-embedded samples were stained with $\mathrm{H} \& \mathrm{E}$, as well as by trichrome Masson staining (Bio-Optica,Italy). For electron microscopy, the skin biopsies were treated with $2.5 \%$ glutaraldehyde with postfixation in $1 \% \mathrm{OsO} 4$, gradually dehydrated in ethanol and acetone and embedded in Epon 812 (Sigma, USA) according by routine technique [7, 8]. Semi-thin slices were stained with methylene blue, azur-2 and basic fuchsin by Humphrey and Pittman [9]. Ultrathin slices were contrasted with uranyl acetate and lead citrate by Reynolds. The examinations were performed at the Libra 120 electron microscope (Carl Zeiss, Germany). 


\section{Results}

\section{Microscopic findings in the patients before HSCT}

In the course of routine morphological examination, the skin of SSD patients before treatment was indurated, being characterized by dystrophy, atrophy, destruction of epidermis, along with sclerotizing and hyalinosis of dermal connective tissue, pathology of vascular microcirculatory flow. Upon polychromic staining of semi-thin slices, we observed bright fuchsinophylia and metachromasia of densely packed thin fibers composing papillary and rough bundles of oedematous reticular dermal layer (Fig. 1, A). Upon trichrome Masson staining, the dermal connective tissue looked dense and intensively blue-coloured.

Upon electron microscopic studies, the collagen fibers were presented by disordered fibril bundles of irregular thickness and optical density, with degradation signs (oedema, decondensation, granular and amorphous destruction). Pathological collagen forms, as cross-linked microfibrillar aggregates were also noted. The ribbon-shaped hyalinized fibers were homogenous and dense. Desquamation of corneal scales and thinning of the layers lead to ruptures and epidermal desquamation, especially in the areas of pronounced subepithelial sclerosis and hyalinosis of connective tissue. Single sebaceous follicles, oil and sweat glands showed the signs of dystrophy.

Microcirculatory network of dermal blood capillaries was changed and showed polymorphic structure, dependent on the degree of connective tissue fibrosis. Upon light microscopy, we observed either capillaries with hypertrophic endothelial cells and proliferating pericytes, or obliterated vessels with homogenized dark or light necrotized lining. EM has showed endothelial necrosis in small capillaries "immured" into the dense fibrotic tissue. The capillaries in deeper dermal layers were lined by pathologically changed dark cells with reduplicated, loosened and fragmented basal membranes. Epithelium in less affected capillaries was surrounded by hyperthrophic pericytes. Apoptotic signs and full destruction of endothelial cells were noted.
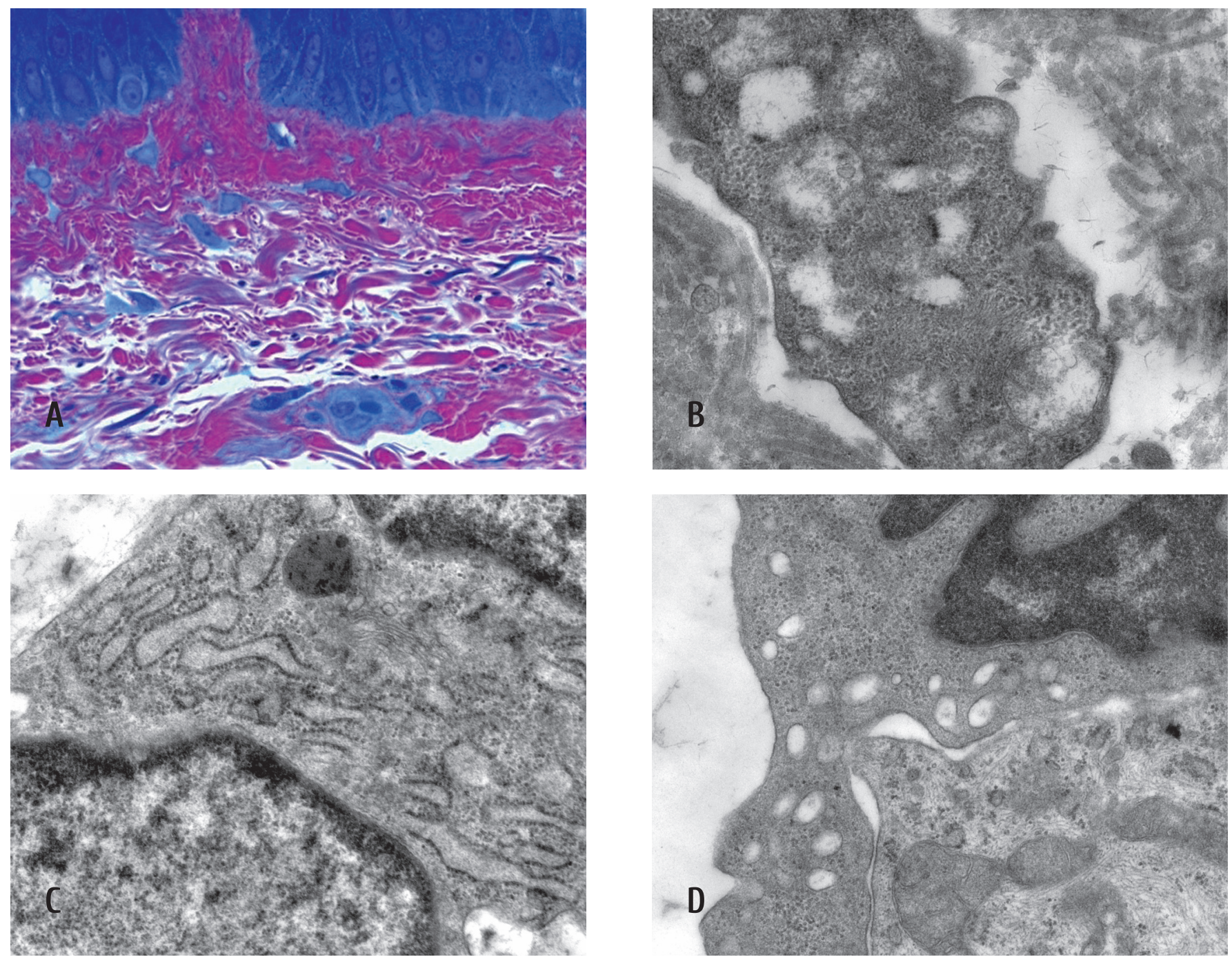

Figure 1. Skin morphology of SSD patients before HSCT: A, fuchsinophilia of sclerotized dermal tissue. Semi-thin slice. Methylene Blue- Azur II, Basic fuchsin staining dye at the 1000x magnification. EM photos: B, myofibroblast with orthodoxal-type mitochondria and vacuolized GER; $C$, activated fibroblast with numerous GER channels and Golgi dictyosomes ; D, lymphocyte with vesicles, dense and slit-like intercellular contact 
Myofibroblasts (MFB) comprised the major dermal cell population, along with non-differentiated cells and fibrocytes. When studied by electron microscopy, the myofibroblasts differed from fibroblasts by pronounced reduction of the cell body with fibrils occupying more than a half of cytoplasmic volume. Electron microscopy of the MFB showed swollen mitochondria, and orthodoxal-type mitochondria with translucent matrix, reduced cristae, destruction of external mitochondrial membrane, as well as vacuolized and destroyed canaliculi of the granular endoplasmatic reticulum (GER), thus suggesting higher activity of these cells (Fig. $1, \mathrm{~B})$. The MFB surrounded by closely adjusted bundles of collagen fibrils were destroyed. The infiltrates composed of lymphocytes, fibroblast-like and mast cells were located in perivascular area. Just there, EM revealed scleroderma-specific fibroblasts, i.e., large elongated or triangle-shaped cells without processes with high synthetic activity, dictyosomes of Golgi complex and well developed GER and flake-like intraluminal substance (Fig. 1, C). The lymphocytes with large hyperchromic nucleus had smooth or villous surface. Dense and fissure-like intrercellular contacts between lymphocytes and fibroblasts were noted, with numerous vesicles in hyaloplasm of some lymphocytes (Fig. 1, D). Scattered fibroclasts with typical plasmalemma protrusions resorbed the collagen fibrils. Detritus and organelles of dead cells were seen between the collagen bundles.

\section{Clinical and morphological changes after HSCT}

Three months after HSCT, the main group of patients exhibited a pronounced clinical effect with sufficient mitigation of skin induration and dysphagia, reduction of muscle contractures, couping vasospasm attacks (Raynaud syndrome).
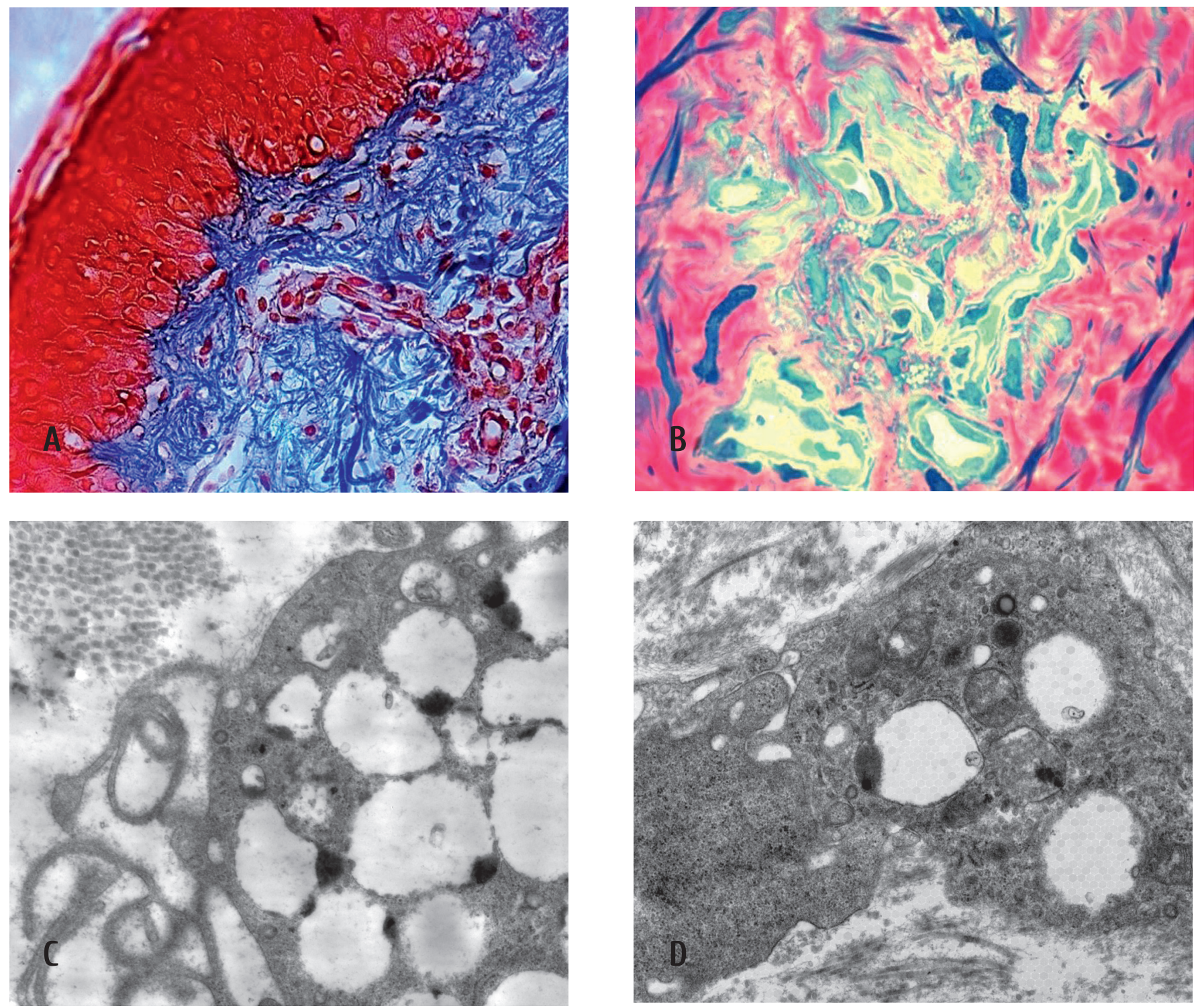

Figure 2. Skin morphology in SSD patients 3 months after autologous HSCT. A, reduction of density and staining intensity of connective tissue. Increased amounts and proliferation of dermal capillaries, trichrome Masson staining; $B$, vessels and macrophages with large vacuoles in the focus of rarefied connective tissue are seen in the semi-thin section stained with Methylene Blue Azur II and basic fuchsine dye at the 1000x magnification. EM photos: C, macrophage with protrusions, large phagocytic vacuoles and small lisosomes; $D$, dense contacts between macrophage and lymphocyte 
Skin density was significantly reduced, with decrease of Rodnan scores by 4.2 points (12.9 to 8.7) compared to 1-point reduction in control group. The SSD disease activity by EScSG criteria was equally diminished from 3.9 to 2.5 points, both in main and control group.

Acanthosis of basal cell layer with inclusions of large vacuoles argued for epidermal regeneration and transdermal fluid transport. Sweat glands and hair follicles appeared. After staining with trichrome Masson decreased density and staining intensity of connective tissue was found, due to reduced collagen deposition (Fig. 2, A). Myofibroblasts, located in papillary layer, acquired elongated form and hyperchromasia. When studied with EM technique, they proved to be altered cells with vacuolized organelles and multiple secondary lysosomes. An increased number of small capillaries with thin walls that were located in papillary layer and even more numerous at the border of reticular layer (Fig. 2, A).

Perivascular space of the de novo formed vessels was characterized by rarefaction of fibrous tissue and occurrence of numerous macrophages with large bright vacuoles (Fig. 2, B). Electron microscopy of capillary endothelium has shown pronounced micropinocytosis. Thin and long protrusions of presumable telocytes were seen in large quantities. These cells had a wide perinuclear and peripheral part which represented thin processes with vacuoles, GER and mitochondria. The intercellular contacts were thin and loosened, with an area of numerous micropinocytic vesicles, or dense and multiple contacts with different cell types. Rare activated fibroblasts had smooth GER contours and pathologically changed mitochondria. We have also seen lymphocyte-like low-differentiated cells with large nuclei and electron-dense hyaloplasm. The macrophages had long protrusions (egrepodes), capturing the degraded material of collagen fibrils. Large electron-bright vacuoles contained the rests of lysed fibrils and small patietally located osmiophylic lysosomes и (Fig. 2, C). Most macrophages contained multiple secondary lysosomes. Fibroclasts also participated in engulfment of collagen fibrils. The macrophages with single large vacuoles without egrepodes and small secretory microvesicles had intercellular contacts with lymphocytes, myofibroblasts and non-differentiated cells (Fig. 2, D).

\section{Discussion}

Myofibroblasts from sclerotized connective tissue of skin in SSD patients before treatment exhibited signs of activation. The more intact partner cells in fibrillogenesis were located in perivascular area, i.e., activated lymphocytes and special scleroderma-associated fibroblast population which produces higher amounts of collagen and intermediate matrix [10]. Mononuclear cell infiltration in the areas of extracellular matrix hyperproduction, like as signs of immunocyte activation in scleroderma presume an important role of immune disturbamces in SSD pathogenesis [11].

Transplantation of cultured HSC promoted biodegradation of fibrotic skin tissue in SSD patients post-transplant. The myofibroblasts were subject to destruction, the numbers and length of capillaries were increased. Cellular composition of perivascular infiltrate was also changed, compared to its previous condition associated with active fibrillogenesis. The numerous emerging phagocytic and secretory macrophages appeared, participating in the isolation of angiogenesis inducers, tissue remodeling, regulation of the number and activity of fibroclasts.

Extensive intercellular interactions of telocytes suggested their participation at neoangiogenesis and transduction of complex signals that regulate regeneration events [12].

\section{Conclusion}

Transplantation of cultured autologous hematopoietic stem cells from the bone marrow to the patients with systemic scleroderma disease promoted biodegradation of sclerotized dermal tissue, stimulation of angiogenesis, restoration of epithelial layer and dermal appendages within 3 months after transplantation, thus correlating with distinct signs of clinical improvement, as shown by decreased Rodnan skin scores.

\section{Acknowledgement}

The study was performed in the frames of National Research Program "Innovative cellular technologies in regenerative medicine" (2013-2015).

\section{Conflict of interests}

None declared.

\section{References}

1. Tindall A, Matucci-Cerenic M, Muller-Lander U. Future targets in the managements of systemic sclerosis. Rheumatology. 2009; 48:49-53.

2. van Laar JM, Tyndall A. Adult stem cell in the treatment of autoimmune diseases. Rheumatology. 2006; 45:1187-1193.

3. Tyndall A. Successes and failures of stem cell transplantation in autoimmune diseases. Hematol Am Soc Hematol Educ Program. 2011; 2011: 280-284.

4. Kissin EY, Merkel PA, Lafyatis R. Myofibroblasts and hyalinized collagen as markers of skin disease in systemic sclerosis. Arthr Rheum. 2006; 54:3655-3660.

5. Joven BE, Escribano P, Andreu JL, Loza E, Jimenez C, Garcia de Yebenes MJ, Ruiz-Cano MJ, Carmona L, Carreira PE. 2013 ACR/EULAR systemic sclerosis classification criteria in patients with associated pulmonary arterial hypertension. Semin Arthritis Rheum. 2018;47(6):870-876.

6. Valentini G, Iudici M, Walker UA, Jaeger VK, Baron M, Carreira P, Czirják L, Denton CP, Distler O, Hachulla E, Herrick AL, Kowal-Bielecka J, Pope J, Müller-Ladner U, Riemekasten G. The European Scleroderma Trials and Research Group (EUSTAR) task force for the development of revised activity criteria for systemic sclerosis: derivation and validation of a preliminarily revised EUSTAR Activity Index. Ann Rheum Dis. 2017; 76(1): 270-276. 
7. Glauert A. Fixation, dehydration and embedding of biological specimens. In: Practical methods in electron microscopy (Ed.: Glauert AM). North-Holland (American Elsevier), 1975.

8. Luft J. Improvements in epoxy resin embedding methods. J Biophys Biochem Cytol. 1961;9:409.

9. Humphrey C, Pittman F. A simple methylene blue-fuze, fuse-stain for epoxy-embedded tissue sections. StainTechnol. 1974;49: 9-14.

10. Santiago B, Galindo M, Rivero M, Pablos JL. Decreased susceptibility to Fas-induced apoptosis of systemic sclerosis dermal fibroblasts. Arthritis Rheum. 2001; 44(7):1667-1676.
11. Nevskaya TA, Guseva IG, Radenska-Lopovok SG, Speransky AI. T cell immune disturbances in earlyv systemic sclerodermia. Nauchno-Prakticheskaya Revmatologiya. 2006; 4: 35-43 (In Russian).

12. Manole CG, Cismasiu V, Gherghiceanu M, Popescu LM. Experimental acute myocardial infarction:telocytes involvement in neo-angiogenesis J Cell Mol Med. 2011; 15(11):22842296. DOI: 10.1111/j.1582-4934.2011.01449.x.

\title{
Морфологическая оценка кожи больных системной склеродермией до и после трансплантации гемо- поэтических стволовых клеток костного мозга
}

\author{
Галина В. Федотовских, Галия М. Шаймарданова, Манарбек Б. Аскаров, Айнаш А. Жусупова, \\ Наталья А. Криворучко, Татьяна Г. Ежеленко, Сапаргуль Марат \\ AO «Национальный научный медицинский центр», г. Нур-Султан (Астана), Казахстан
}

\section{Резюме}

Результаты клинических отчетов по оценке трансплантации гемопоэтических стволовых клеток (ГСК) при лечении тяжелых форм различных аутоиммунных заболеваний являются обнадеживающими. В гистологический контроль динамики фиброза кожи в процессе лечения больных системной склеродермией (ССД), как правило, включается счет миофибробластов, отвечающих за избыточное отложение компонентов внеклеточного матрикса. Цель исследования состояла в оценке морфофункционального состояния кожи больных системной склеродермией до и после трансплантации аутологичных гемопоэтических стволовых клеток костного мозга.

\section{Пациенты и методы}

Под клиническим наблюдением в Национальном научном медицинском центре г. Нур-Султана находилось 28 больных, средний возраст 45+11 лет (мужчин 2, женщин 26) с достоверным диагнозом ССД согласно ACR/EULAR, 2013. Продолжительность заболевания составляла $12+5,4$ года. Контрольную группу, получавшую базисную терапию составляли 12 человек. В протокол лечения основной группы (16 человек) дополнительно включали трансфузию ГСК. Основанием для проведения трансплантации стволовых клеток послужила резистентность к иммуносупрессивной терапии.
После клинико-лабораторного обследования больных ССД проводилась аспирация костного мозга из гребня подвздошной кости в количестве 200300 мл под местной или эпидуральной анестезией в стерильных условиях хирургического отделения. Выделение мононуклеарных клеток полученных из аутологичных клеток костного мозга, проводили центрифугированием после наслоения на градиентную среду плотности с использованием Percoll (Sigma Aldrich, P1644). Выделенные клетки культивировали в среде DMEM (среда Игла, модифицированная Dulbecco, Sigma Aldrich, D1145) с 10\% FBS при $37^{\circ} \mathrm{C}$ в течение 72 часов. Жизнеспособность клеток определяли окрашиванием трипановым синим. Количественное определение двойных положительных CD45 + / CD34 + мононуклеарных клеток проводили на проточном цитометре BD FACSCalibur (США). Переливание аутологичных культивированных HSC проводили в физиологическом растворе (в среднем $140 \times 106$ клеток на 200 мл) внутривенно капельно со скоростью 50 мл/ч. Клиническую эффективность (оценки по шкале Роднана) оценивали по критериям Европейской группы исследований и исследований по склеродермии (2017).

Материалом для морфологического исследования послужил биопсийный материал кожи голени, взятый методом панч-биопсии у 15 пациентов до клеточной терапии и у 9 пациентов через 3 месяца после трансплантации при клиническом улучшении состояния кожных покровов. Гистологические парафиновые 
срезы окрашивались гематоксилином и эозином, а также по Массон - трихром. Для электронной микроскопии биопсийные кусочки кожи проводили по общепринятой методике и заключали в Эпон. Полутонкие срезы окрашивали метиленовым синим, азуром - 2 и основным фуксином по C. Humphrey и F. Pittman [5]. Ультратонкие срезы для ЭМ контрастировали уранилацетатом и цитратом свинца.

\section{Результаты}

Кожа больных ССД до лечения находилась в состоянии индурации и характеризовалась дистрофией, атрофией и деструкцией эпидермиса, склерозированием и гиалинозом соединительной ткани дермы, патологией сосудов микроциркуляторного русла. Ультраструктура миофибробластов, расположенных в склерозированной дерме характеризовалась признаками функциональной перегрузки. Активные участники процесса фибрилогенеза располагались в периваскулярной зоне и были представлены лимфоцитами и фибробластами особой склеродермаспецифической популяции, продуцирующими повышенное количество коллагена и межуточного матрикса.

Через три месяца после трансплантации ГСК в основной группе пациентов отмечался выраженный клинический эффект со значительным уменьшением индурации кожи, дисфагии, купировались мышечные контрактуры, уменьшались приступы вазоспазма (синдром Рейно). Достоверно уменьшались плотность кожи со снижением кожного счета по Роднану на 4,2 балла с 12,9 до 8,7 (в контрольной группе - лишь на 1 балл). Трансплантация ГСК способствовала биодеградации фиброзной ткани кожи больных ССД основной группы. Подвергались деструкции миофибробласты, увеличивалось количество и протяженность капилляров, менялся клеточный состав периваскулярного инфильтрата, направленный ранее на активный процесс фибрилогенеза. Появлялись многочисленные фагоцитарные и секреторные макрофаги, участвующие в выделении индукторов ангиогенеза, ремоделировании ткани, регуляции количества и активности фиброкластов, супрессии Т- и В-лимфоцитарных механизмов иммунитета, играющих важную роль в патогенезе ССД. Обширные межклеточные связи, предположительно, телоцитов свидетельствовали об их участии в неоангиогенезе и передаче сложных регулирующих сигналов в процессе регенерации.

\section{Выводы}

Трансплантация культивированных аутологичных гемопоэтических стволовых клеток костного мозга больным ССД способствовала биодеградации склерозированной ткани дермы, стимуляции ангиогенеза, восстановлению эпителия и придатков кожи через 3 месяца после трансплантации, что соответствовало признакам улучшения клинической симптоматики.

\section{Ключевые слова}

Системная склеродермия, трансплантация гемопоэтических стволовых клеток, костный мозг, морфология кожи. 